\title{
Influence of Alkaline Activators on Unconfined Compressive Strength of Saline Soils Stabilised with Ground Granulated Blast Furnace Slags
}

\author{
Guoqi Xing $\mathbb{D}^{1},{ }^{1}$ Lijun Zhang, ${ }^{2}$ Wei Xuan, ${ }^{1}$ Yueyue Pan, ${ }^{1}$ Yue Zhao, ${ }^{1}$ and Bing Zhang ${ }^{1}$ \\ ${ }^{1}$ College of Architectural Engineering, Weifang University, Weifang, Shandong, China \\ ${ }^{2}$ Jinan Municipal Engineering Construction Group Co., Ltd., Jinan, Shandong, China \\ Correspondence should be addressed to Guoqi Xing; xgq1105@163.com
}

Received 1 August 2020; Revised 19 October 2021; Accepted 6 November 2021; Published 23 November 2021

Academic Editor: Guojun Wu

Copyright (c) 2021 Guoqi Xing et al. This is an open access article distributed under the Creative Commons Attribution License, which permits unrestricted use, distribution, and reproduction in any medium, provided the original work is properly cited.

To mitigate the environmental impact induced by $\mathrm{CO}_{2}$ emissions and nonrenewable resource consumption, which are typically associated with Portland cement production, ground granulated blast furnace slags (GGBSs) are usually added to the cement. In this study, the stabilisation effect of alkali-activated GGBS on saline soil and the hydration products of alkali-activated GGBS were investigated by unconfined compressive strength tests and scanning electron microscopy, respectively. The results show that $\mathrm{Ca}(\mathrm{OH})_{2}$ and $\mathrm{NaOH}$ as alkaline activators for GGBS significantly improve the unconfined compressive strength of saline soils. This strength is also enhanced by $\mathrm{Na}_{2} \mathrm{SO}_{4}$; however, the increase is considerably less than that provided by $\mathrm{Ca}(\mathrm{OH})_{2}$ and $\mathrm{NaOH}$. In contrast, $\mathrm{Na}_{2} \mathrm{CO}_{3}$ is not a suitable alkaline activator for GGBS and has no significant effect on the unconfined compressive strength of saline soils. The study results further show that the morphology of hydration products varies because of the different alkaline activators involved in the hydration reaction with GGBS in saline soils.

\section{Introduction}

Saline soils are mainly found in coastlands or lakes in western China [1]. They contain many soluble salts, such as $\mathrm{NaCl}, \mathrm{KCl}, \mathrm{CaCl}_{2}, \mathrm{Na}_{2} \mathrm{SO}_{4}, \mathrm{MgSO}_{4}, \mathrm{Na}_{2} \mathrm{CO}_{3}$, and $\mathrm{NaHCO}_{3}$ [2]; consequently, numerous plants cannot grow in these soils [3]. When temperature drops, $\mathrm{Na}_{2} \mathrm{SO}_{4}$ and $\mathrm{Na}_{2} \mathrm{CO}_{3}$ can separate from saline soils because their solubility decreases, increasing soil volume (i.e., salt heaving). In contrast, when temperature rises, the soil volume decreases due to increased solubility, resulting in the collapse of saline soils [4]. As a result, saline soils cannot be directly used for subgrade engineering or foundation engineering; they must first be treated before they can be applied to engineering work. For this purpose, Portland cement is generally employed to stabilise saline soils [5].

However, the production process of Portland cement generates environmental pollutants. For example, it produces considerable amounts of carbon dioxide, which further aggravate the greenhouse effect and contaminate the atmosphere [6]. Moreover, many nonrenewable energy resources, such as coal and petroleum, are used in cement production [7]. Thus, alternative inorganic binders must be used in lieu of Portland cement to stabilise saline soils.

The substitution of Portland cement with inorganic binders has been investigated by some researchers. For example, Jegandan et al. [8] found that blended materials, including ground granulated blast furnace slag (GGBS), pulverised fuel ash, cement kiln dust, zeolite, and reactive magnesia, could improve the mechanical performance and durability of stabilised soils ranging from sand and gravel to clay. Kavak et al. [9] investigated the use of GGBS (powder form), commercial lime, and seawater to improve the engineering properties of clay soil with low plasticity. Their study showed that the unconfined compressive strength of clay samples (stabilised with 5\% lime and 3.33\% GGBS; cured for $28 \mathrm{~d}$ ) was more than eight times the initial strength of untreated samples, reaching $2.5 \mathrm{MPa}$ in the presence of 
seawater. Laxmikant [10] applied a mixture of GGBS and fly ash to stabilise soft soil. Based on compaction and California bearing ratio test results, the optimum amounts of GGBS and fly ash for stabilisation were $6 \%$ and $3 \%$, respectively. With this optimum combination, reasonable improvement in the California bearing ratio values was observed for unsoaked and soaked soils. Rashad [11] presented an overview of previous studies on the use of high-volume Class F fly ash as partial cement replacement in traditional paste-mortar-concrete mixtures based on Portland cement. In [12], Rashad summarised earlier investigation reports that focused on the use $45 \%$ volume Class $\mathrm{F}$ fly ash as cement replacement in such mixtures. Yi et al. [13] implemented a series of tests, including unconfined compressive strength test, X-ray diffraction, and scanning electron microscopy. Their objective was to investigate the influence of different alkaline activators, such as $\mathrm{MgO}, \mathrm{Mg}(\mathrm{OH})_{2}$, and $\mathrm{Ca}(\mathrm{OH})_{2}$, on soils stabilised with GGBS. The results indicated that $\mathrm{Mg}(\mathrm{OH})_{2}$ had minimal activating efficacy on soil with GGBS; between $\mathrm{MgO}$ and $\mathrm{Ca}(\mathrm{OH})_{2}$, the former had greater efficacy. Moreover, the common hydration products in all stabilised soils with different alkaline activators and GGBS were calcium silicate hydrate-like compounds. Thomas et al. [14] investigated the influence of various dosages of alkaliactivated GGBS and enzymes on the physical and mechanical properties of soil. They found that soil strength significantly increased with the addition of stabilisers, increasing the optimum moisture content, unconfined compressive strength (UCS), and shear strength parameters. Furthermore, the cohesion of soil samples significantly improved with the addition of stabilisers; however, the change in internal friction was marginal. Payá et al. [15] adopted olive stone biomass ash as alkaline activator, and its mixture with GGBS was used to prepare compacted dolomitic soil blocks. The compressive test results indicate that the final compressive strength of these blocks cure for $120 \mathrm{~d}$ was $27.8 \mathrm{MPa}$, indicating that olive stone biomass ash was a sustainable alkaline activator alternative. Based on the above papers, it can be concluded that the application of the binders described above to soil stabilisation has extensive prospects.

Yi et al. [16] conducted a series of experiments to demonstrate that $\mathrm{Na}_{2} \mathrm{SO}_{4}$ and $\mathrm{Na}_{2} \mathrm{CO}_{3}$ could be used as alkaline activators for GGBS. Their use in saline soils can prevent the collapse and heaving of these soils because both participate in the hydration reaction with GGBS. Hence, the application of alkali-activated GGBS to stabilise saline soils has scientific significance. In this study, four types of alkaline activators, namely, $\mathrm{Na}_{2} \mathrm{SO}_{4}, \mathrm{Na}_{2} \mathrm{CO}_{3}, \mathrm{NaOH}$, and $\mathrm{Ca}(\mathrm{OH})_{2}$, for GGBS to stabilise saline soils were investigated. Moreover, the morphology of hydration products of different alkaline activators involved in the hydration reaction with GGBS in saline soils was also investigated.

\section{Materials and Experimental Programme}

2.1. Materials. Saline soil samples (Figure 1) were collected from soil deposits in Binhai economic development zone in Weifang, China; Table 1 lists the physical properties of these

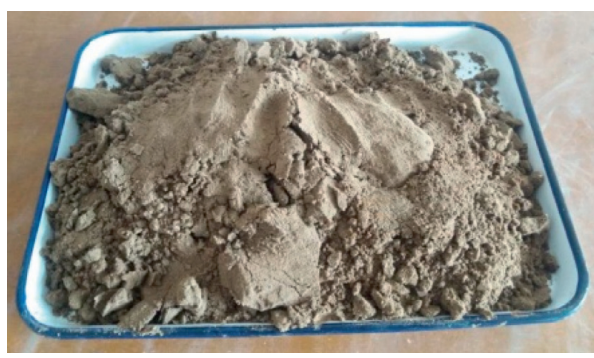

Figure 1: Saline soil used in test.

samples. Based on Chinese design codes $[17,18]$ and Table 1, the saline soils used in the test are classified as sandy silt. Figure 2 shows the grain size accumulation curve of saline soils, indicating that the soil samples have poor particle grading. Table 2 summarises the various ion contents derived by chemical analysis. Based on the results listed in Table 2, the calculated sum of moles of $\mathrm{CO}_{3}{ }^{-2}$ and $\mathrm{HCO}_{3}{ }^{-}$in saline soils is $11.8 \mathrm{mmol}$. This value exceeds $0.3 \mathrm{mmol}$, indicating the alkalinity of saline soil samples [19].

The chemical composition and performance of GGBS are listed in Table 3 , and the properties of $\mathrm{NaOH}, \mathrm{Na}_{2} \mathrm{CO}_{3}$, $\mathrm{Na}_{2} \mathrm{SO}_{4}$, and $\mathrm{Ca}(\mathrm{OH})_{2}$ alkaline activators are summarised in Table 4. Portland cement (42.5) was also used to stabilise the saline soil samples in the test. Table 5 summarises the main chemical composition and performance of Portland cement.

2.2. Test Procedure. In this study, the mixture of GGBS and alkaline activators (or cement) are called inorganic binders. The inorganic binder and water contents are defined as

$$
\begin{aligned}
& W_{b}=\frac{T_{b}}{T_{s}+T_{b}} \times 100 \%, \\
& W_{w}=\frac{T_{w}}{T_{s}+T_{b}} \times 100 \%,
\end{aligned}
$$

where $T_{s}, T_{w}$, and $T_{b}$ are the masses of dried saline soils, water, and inorganic binders, respectively. In addition, $T_{b}$ is the sum of the masses of alkaline activators and GGBS.

Based on the Chinese design code [20], the optimal moisture content of saline soil samples is $18.7 \%$, which is obtained using a standard compaction test. Therefore, considering the hydration reaction of inorganic binders, $W_{w}$ for all samples was set to $30.0 \%$, which is higher than the aforementioned optimal moisture content. In addition, the Chinese design code [21] suggests $W_{b}$ to be in the range $3.0 \%-25.0 \%$. Thus, based on the empirical mix proportion design for composite cement and saline soils, $W_{b}$ for all samples was set to $23.1 \%$ in this study.

Shi et al. [22] investigated the alkali excitation of $\mathrm{NaOH}$ on GGBS and concluded that the optimum $\mathrm{NaOH}$ content was $5 \%$ of the water content in the mixture. They recommended that the number of moles of $\mathrm{Na}_{2} \mathrm{CO}_{3}$ was equal to half the number of moles of $\mathrm{NaOH}$ in the mixture. In China, three-to-seven lime loess samples (the volume ratio of lime to loess is $3: 7$ ) are used to stabilise soils [23]. For $\mathrm{Na}_{2} \mathrm{SO}_{4}$, Wang et al. [24] assumed that when the mass of sodium 
TABLe 1: Physical properties of saline soils.

\begin{tabular}{|c|c|c|c|c|c|c|c|c|}
\hline \multirow[b]{2}{*}{$\begin{array}{l}\text { Specific } \\
\text { gravity, } G_{s}\end{array}$} & \multicolumn{3}{|c|}{ Consistency index } & \multicolumn{2}{|c|}{ Compaction test } & \multicolumn{3}{|c|}{ Grain content (\%) } \\
\hline & $\begin{array}{l}\text { Liquid } \\
\text { limit, } w_{\mathrm{L}} \\
\quad(\%)\end{array}$ & $\begin{array}{l}\text { Plastic } \\
\text { limit, } w_{\mathrm{p}} \\
\quad(\%)\end{array}$ & $\begin{array}{c}\text { Plastic } \\
\text { index, } I_{P}\end{array}$ & $\begin{array}{c}\text { Maximum dry } \\
\text { density, } \rho_{\mathrm{d}}\left(\mathrm{g} \cdot \mathrm{cm}^{-3}\right)\end{array}$ & $\begin{array}{l}\text { Optimum water } \\
\text { content, } s(\%)\end{array}$ & $\begin{array}{l}0.25-0.075 \\
\quad(\mathrm{~mm})\end{array}$ & $\begin{array}{c}0.075-0.005 \\
(\mathrm{~mm})\end{array}$ & $\begin{array}{c}<0.005 \\
(\mathrm{~mm})\end{array}$ \\
\hline 2.67 & 30.5 & 21.6 & 8.9 & 1.87 & 18.7 & 20.97 & 69.51 & 9.52 \\
\hline
\end{tabular}

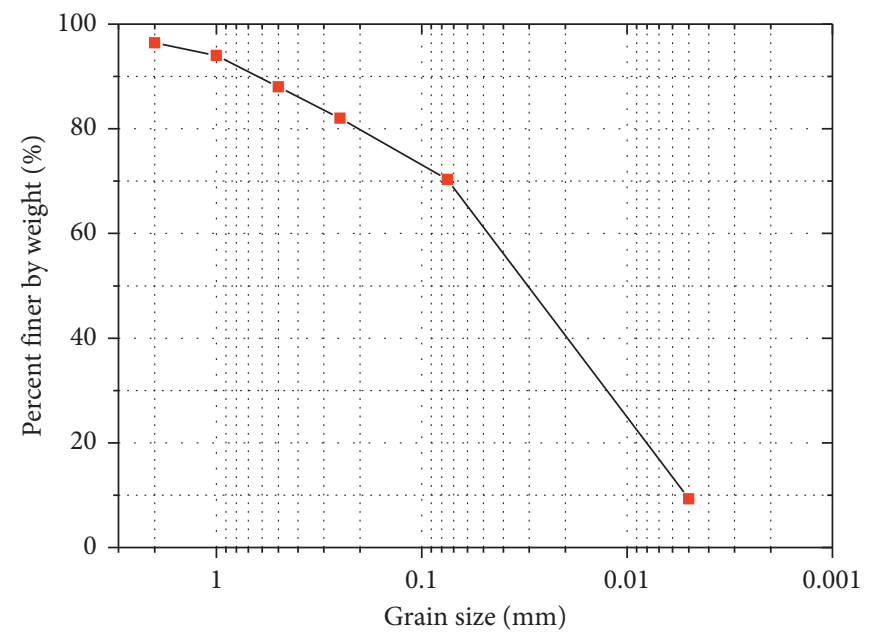

FIGURE 2: Grain size distribution curve.

TABLE 2: Ion content of saline soils (mg).

\begin{tabular}{lccccccc}
\hline $\mathrm{CO}_{3}{ }^{2-}$ & $\mathrm{HCO}_{3}{ }^{-}$ & $\mathrm{CI}^{-}$ & $\mathrm{SO}_{4}{ }^{2-}$ & $\mathrm{Ca}^{2+}$ & $\mathrm{Mg}^{2+}$ & $\mathrm{K}^{+}+\mathrm{Na}^{+}$ & $\mathrm{pH}^{+}$value \\
\hline 403.6 & 310.2 & 9032.5 & 5646.1 & 989.4 & 1012.7 & 6138.7 \\
\hline
\end{tabular}

* Saline soil mass used in chemical analysis is $1000 \mathrm{~g}$.

TABLE 3: Main chemical composition and performance of GGBS.

\begin{tabular}{|c|c|c|c|c|c|c|c|c|c|}
\hline \multicolumn{7}{|c|}{ Main chemical compositions } & \multirow[b]{2}{*}{$\begin{array}{l}\text { Blaine surface area } \\
\qquad\left(\mathrm{m}^{2} / \mathrm{kg}\right)\end{array}$} & \multirow[b]{2}{*}{$\begin{array}{c}\text { Fluidity ratio } \\
(\%)\end{array}$} & \multirow[b]{2}{*}{$\begin{array}{l}\text { Activity index } \\
(28 \mathrm{~d})(\%)\end{array}$} \\
\hline $\begin{array}{l}\mathrm{SiO}_{2} \\
(\%)\end{array}$ & $\begin{array}{c}\mathrm{Al}_{2} \mathrm{O}_{3} \\
(\%)\end{array}$ & $\begin{array}{l}\mathrm{Fe}_{2} \mathrm{O}_{3} \\
(\%)\end{array}$ & $\begin{array}{c}\mathrm{CaO} \\
(\%)\end{array}$ & $\begin{array}{c}\mathrm{MgO} \\
(\%)\end{array}$ & $\begin{array}{c}\text { Loss on } \\
\text { ignition (\%) }\end{array}$ & $\begin{array}{l}\text { Specific } \\
\text { gravity, } G_{s}\end{array}$ & & & \\
\hline 34.2 & 14.7 & 0.27 & 39.8 & 0.25 & 0.8 & 2.9 & 506 & 104 & 115 \\
\hline
\end{tabular}

TABle 4: Properties of $\mathrm{NaOH}, \mathrm{Na}_{2} \mathrm{CO}_{3}, \mathrm{Na}_{2} \mathrm{SO}_{4}$, and $\mathrm{Ca}(\mathrm{OH})_{2}$ alkaline activators.

\begin{tabular}{lcccc}
\hline & Specific gravity $G_{s}$ & Melting point $\left({ }^{\circ} \mathrm{C}\right)$ & Boiling point $\left({ }^{\circ} \mathrm{C}\right)$ & Morphology \\
\hline $\mathrm{NaOH}$ & 2.13 & 318 & 1388 & Schistose or granular \\
$\mathrm{Na}_{2} \mathrm{CO}_{3}$ & 2.532 & 851 & 1600 & White powder \\
$\mathrm{Na}_{2} \mathrm{SO}_{4}$ & 2.68 & 884 & 1404 & Transparent crystal \\
$\mathrm{Ca}(\mathrm{OH})_{2}$ & 74 & 580 & 2850 & White powdery solid \\
\hline
\end{tabular}

TABle 5: Main chemical composition and performance of Portland cement (42.5).

\begin{tabular}{|c|c|c|c|c|c|c|c|c|}
\hline $\mathrm{SiO}_{2}(\%)$ & $\mathrm{Al}_{2} \mathrm{O}_{3}(\%)$ & $\mathrm{Fe}_{2} \mathrm{O}_{3}(\%)$ & $\mathrm{CaO}(\%)$ & $\mathrm{MgO}(\%)$ & $\mathrm{SO}_{3}(\%)$ & Loss on ignition (\%) & Blaine surface area $\left(\mathrm{m}^{2} / \mathrm{kg}\right)$ & Specific gravity, $G_{s}$ \\
\hline 29.05 & 7.54 & 2.97 & 50.55 & 2.19 & 2.29 & 4.09 & 382 & 2.88 \\
\hline
\end{tabular}


sulphate was $3 \%$ of fly ash mass, the activity of fly ash could be well stimulated.

The following experimental schemes listed in Table 6 are designed based on the results of the above studies; the optimum content of alkaline activators for GGBS in saline soils can be obtained from these schemes.

2.3. Processing of Specimens. Based on the standard soil test method specified by the Chinese code [25], samples whose diameter and height are 39.1 and $80 \mathrm{~mm}$, respectively, are used to investigate the UCS of saline soils stabilised with inorganic binders. First, the saline soils were dried for at least $12 \mathrm{~h}$ in an electric blast drying oven and then broken into pieces. Soil particles larger than $2 \mathrm{~mm}$ were screened out using a soil sieve. To facilitate the removal of specimens from moulds and avoid specimen fracture, the interior of moulds was lubricated.

The masses of alkaline activators, GGBS, and dried saline soils can be determined from the experimental schemes summarised in Table 6. Alkaline activators and GGBS were homogeneously mixed. Then, dried saline soils were added to the mixture and stirred homogeneously. Finally, water was poured into the mixture and further stirred to ensure homogeneity.

Before pouring the homogeneous mixture into a mould, it was divided into three equal parts; these were poured one at a time into the mould for compaction. To integrate the three parts, the surface of each compressive layer was scoured to create a bond between two compressive layers. After removing a specimen from the mould, it was wrapped with a plastic membrane and then placed in a curing chamber for $7,28,56$, and $90 \mathrm{~d}$.

2.4. Test Procedure and Instrumentation. To ensure the repeatability of experiments, each set of experiments included a minimum of six samples. In addition, unconfined compressive tests were implemented on the last day of curing. Scanning electron microscopy was performed after curing the specimens for $90 \mathrm{~d}$. Moreover, to prevent the further hydration reaction of samples, these were broken into fragments and then soaked in anhydrous alcohol for a minimum of $48 \mathrm{~h}$. After soaking, they were dried in a vacuum environment, and after drying, scanning electron microscopy was performed.

Two main instruments were used: a conventional unconfined compressive apparatus and a scanning electron microscope, as shown in Figures 3(a) and 3(b), respectively. The conventional unconfined compressive apparatus was modified such that it could automatically record the load and displacement detected by the load cell sensor and displacement transducer, respectively. In the unconfined compressive test, the loading rate of the apparatus was $2.4 \mathrm{~mm} / \mathrm{min}$. Each sample was tested until it was damaged. The microstructure morphology of each sample was obtained by scanning electron microscopy.

\section{Results and Discussions}

Figure 4 shows the variation in the UCS of remoulded saline soil samples during the curing period. The figure indicates that even during the $90 \mathrm{~d}$ curing period, the UCS of remoulded saline soils is only $0.011 \mathrm{MPa}$, which is extremely low. Hence, saline soils must first be treated before they can be used for subgrade or foundation engineering.

3.1. Saline Soils Stabilised with $\mathrm{Ca}(\mathrm{OH})_{2}$ and Portland Cement. Figure 5 shows the variation in the UCS of saline soils stabilised with $\mathrm{Ca}(\mathrm{OH})_{2}$ and Portland cement during the curing period. As indicated by this figure, Portland cement is better than $\mathrm{Ca}(\mathrm{OH})_{2}$ as an inorganic binder for saline soils. As listed in Table 6, the volume ratio of $\mathrm{Ca}(\mathrm{OH})_{2}$ to saline soils is $3: 7$; in China, this is called three-to-seven lime loess. The material is used as cushion for foundations or applied to lime soil compaction piles to reduce soil compressibility and increase soil bearing capacity.

Figures 6(a) and 6(b) show the microstructure of saline soils stabilised with $\mathrm{Ca}(\mathrm{OH})_{2}$. As shown in Figure 6(b), hydration products fill the spaces in-between saline soil particles; the products resemble crystalloids.

When water is poured into the homogeneous mixture of $\mathrm{Ca}(\mathrm{OH})_{2}$ and saline soils, $\mathrm{Ca}(\mathrm{OH})_{2}$ becomes $\mathrm{CaCO}_{3}$ according to the following chemical reaction.

$$
\mathrm{Ca}(\mathrm{OH})_{2}+\mathrm{CO}_{2}+\mathrm{H}_{2} \mathrm{O} \longrightarrow \mathrm{CaCO}_{3}+2 \mathrm{H}_{2} \mathrm{O}
$$

Because $\mathrm{CaCO}_{3}$ is produced, the hydration rate decelerates. This is because $\mathrm{CaCO}_{3}$ prevents the entry of $\mathrm{CO}_{2}$ into the mixture of $\mathrm{Ca}(\mathrm{OH})_{2}$ and saline soils and precludes water from evaporating. Thus, improving the strength of saline soils is limited when $\mathrm{Ca}(\mathrm{OH})_{2}$ is used.

Figures $7(a)-7(c)$ show the microstructure of saline soils stabilised with Portland cement. Numerous soil particles are virtually enclosed by hydration products, as shown in Figures $7(\mathrm{~b})$ and $7(\mathrm{c})$. This can considerably improve the strength of saline soils, as indicated in Figure 5. Figures 7(b) and $7(\mathrm{c})$ show two types of hydration products, one resembling a reticular gel and another similar to an acicular crystal.

3.2. Saline Soils Stabilised with Mixtures of $\mathrm{Ca}(\mathrm{OH})_{2}$ and GGBS. Figure 8 shows the variation in the UCS of saline soils stabilised with $\mathrm{Ca}(\mathrm{OH})_{2}$ and GGBS during the curing period. For samples 4, 5, 6, 7, 8, 9, and 10 listed in Table 6, the mixtures of $\mathrm{Ca}(\mathrm{OH})_{2}$ and GGBS as well as the mass of inorganic binders are kept constant. However, the mass ratio of $\mathrm{Ca}(\mathrm{OH})_{2}$ to $\mathrm{GGBS}$ varies for inorganic binders.

In Figure 8, sample 2 represents three-to-seven lime loess. As listed in Table 6, for samples 4, 5, 6, 7, 8, 9, and 10, the GGBS content is gradually increased. As indicated in Figure 8, the UCS of saline soil samples stabilised with inorganic binders increases with the curing period. Based on this figure, the influence of $\mathrm{Ca}(\mathrm{OH})_{2}$ content in inorganic 
TABLE 6: Experiment scheme for saline soils sample.

\begin{tabular}{|c|c|c|c|c|c|c|c|}
\hline Sample no. & Dried saline soils (\%) & $\mathrm{NaOH}(\%)$ & $\mathrm{Na}_{2} \mathrm{CO}_{3}(\%)$ & $\mathrm{Na}_{2} \mathrm{SO}_{4}(\%)$ & $\mathrm{Ca}(\mathrm{OH})_{2}(\%)$ & Portland cement (\%) & GGBS (\%) \\
\hline 1 & 100 & - & - & - & - & - & - \\
\hline 2 & 76.9 & - & - & - & 23.1 & - & - \\
\hline 3 & 76.9 & - & - & - & - & 23.1 & - \\
\hline 4 & 76.9 & - & - & - & 16.17 & & 6.93 \\
\hline 5 & 76.9 & - & - & - & 13.86 & & 9.24 \\
\hline 6 & 76.9 & - & - & - & 11.55 & - & 11.55 \\
\hline 7 & 76.9 & - & - & - & 9.24 & & 13.86 \\
\hline 8 & 76.9 & - & - & - & 6.93 & - & 16.17 \\
\hline 9 & 76.9 & & & & 4.62 & & 18.48 \\
\hline 10 & 76.9 & - & - & - & 2.31 & - & 20.79 \\
\hline 11 & 76.9 & 0.12 & - & - & - & - & 22.98 \\
\hline 12 & 76.9 & 0.24 & - & - & - & - & 22.86 \\
\hline 13 & 76.9 & 0.36 & & & & & 22.74 \\
\hline 14 & 76.9 & 0.48 & - & - & - & - & 22.62 \\
\hline 15 & 76.9 & 0.96 & - & - & - & - & 22.14 \\
\hline 16 & 76.9 & 1.39 & - & - & - & - & 21.66 \\
\hline 17 & 76.9 & 1.56 & & & & & 21.54 \\
\hline 18 & 76.9 & 1.68 & & & & & 21.42 \\
\hline 19 & 76.9 & - & 0.82 & - & - & - & 22.28 \\
\hline 20 & 76.9 & - & 1.30 & - & - & - & 21.80 \\
\hline 21 & 76.9 & - & 2.40 & - & - & - & 20.70 \\
\hline 22 & 76.9 & & 3.50 & & & & 19.60 \\
\hline 23 & 76.9 & & 4.60 & & & & 18.50 \\
\hline 24 & 76.9 & - & - & 0.24 & - & - & 22.86 \\
\hline 25 & 76.9 & - & - & 0.46 & - & - & 22.64 \\
\hline 26 & 76.9 & - & - & 0.67 & - & - & 22.43 \\
\hline 27 & 76.9 & & & 0.89 & & & 22.21 \\
\hline 28 & 76.9 & - & - & 1.11 & - & - & 21.99 \\
\hline 29 & 76.9 & - & - & 1.33 & - & - & 21.77 \\
\hline 30 & 76.9 & & & 1.54 & & & 21.56 \\
\hline
\end{tabular}

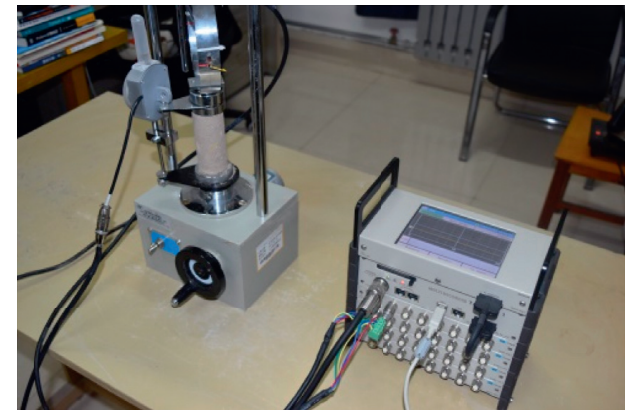

(a)

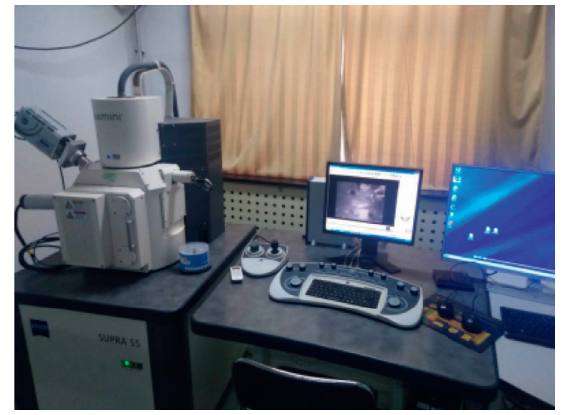

(b)

Figure 3: Apparatus used in test. (a) Unconfined compressive apparatus and (b) scanning electron microscope.

binders on the UCS of samples during the $90 \mathrm{~d}$ curing period can be derived, as shown in Figure 9.

Figure 9 indicates that, with decreasing $\mathrm{Ca}(\mathrm{OH})_{2}$ content in inorganic binders, the UCS of the sample initially increases until it reaches the maximum $(0.60 \mathrm{MPa})$; then, the strength decreases. This is because the redundance of $\mathrm{Ca}(\mathrm{OH})_{2}$ cannot effectively stimulate GGBS, which is responsible for increasing sample strength. The figure further shows that the maximal UCS of the sample stabilised with the abovementioned inorganic binders approximates that of the sample stabilised with Portland cement during the
$90 \mathrm{~d}$ curing period. Consistent with the report of James et al. [26], this indicates that $\mathrm{Ca}(\mathrm{OH})_{2}$ is a satisfactory alkaline activator of GGBS.

Based on the least squares method, the test results in Figure 9 can be fitted as follows:

$$
P_{u}=\frac{5.65-5.4 m}{1-1.26 m+7.23 m^{2}}
$$

where $P_{u}$ represents the UCS $(\mathrm{MPa})$ and $m$ represents the $\mathrm{Ca}(\mathrm{OH})_{2}$ content in inorganic binders (\%). In equation (3), parameter $m$ is in the range $10 \%-100 \%$. 


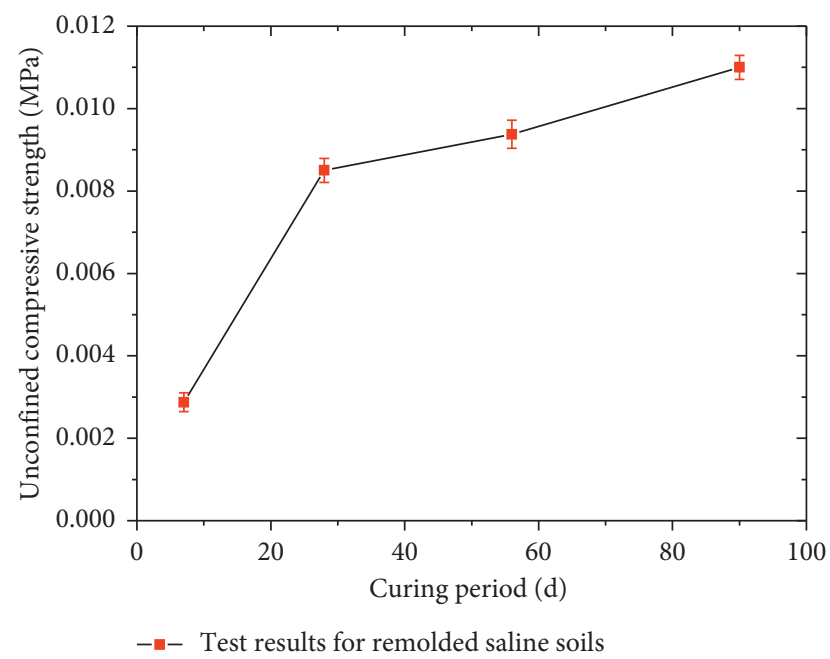

FIGURE 4: Variation in UCS of remoulded saline soils during curing period.

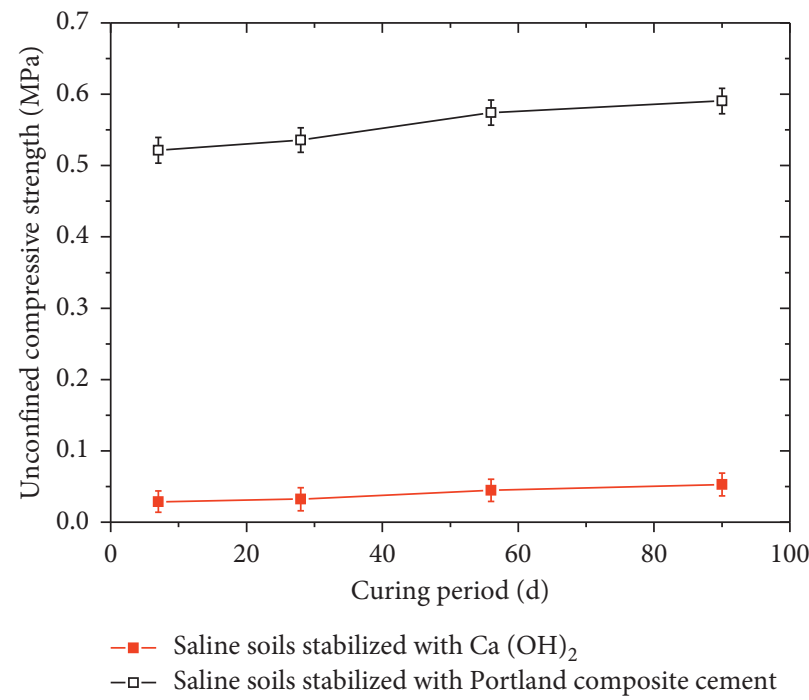

FIGURE 5: Variation in UCS during curing period of saline soils stabilised with $\mathrm{Ca}(\mathrm{OH})_{2}$ and Portland cement.

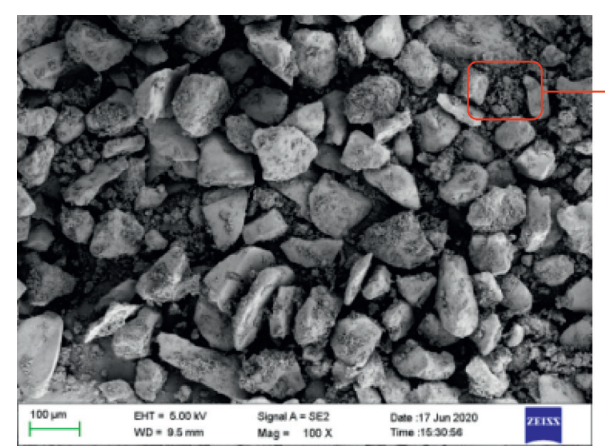

(a)

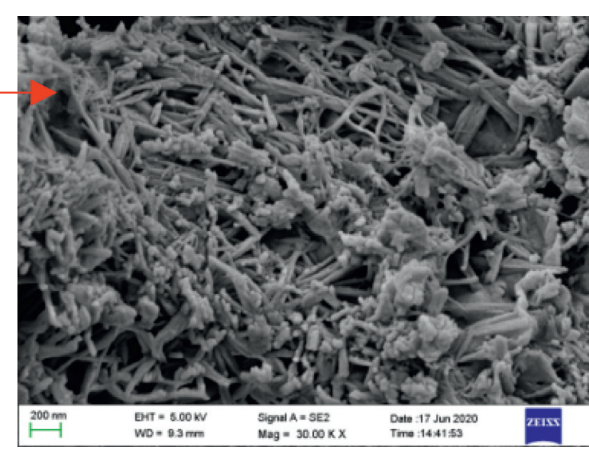

(b)

Figure 6: Microstructure of saline soils stabilised with $\mathrm{Ca}(\mathrm{OH})_{2}$. (a) Close-up of sample and (b) hydration products. 


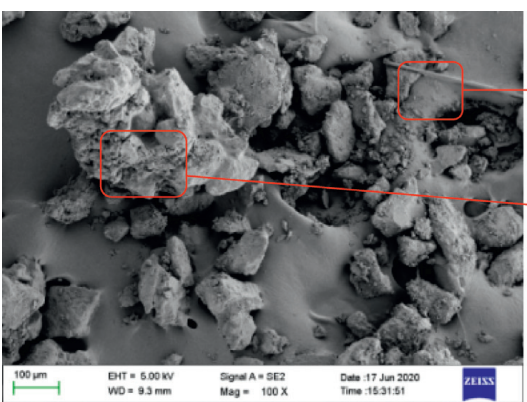

(a)

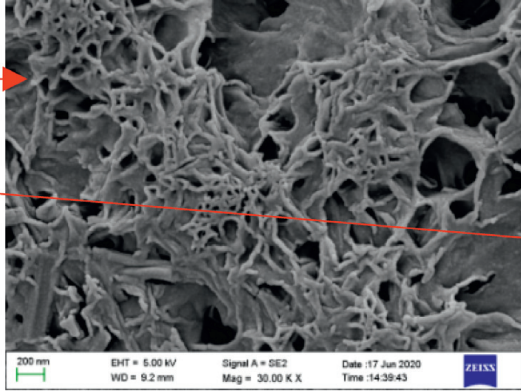

(b)

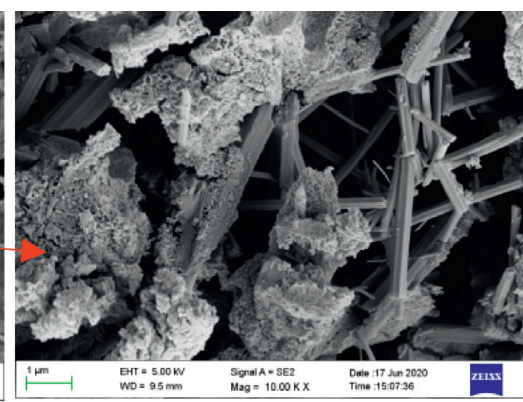

(c)

Figure 7: Microstructure of saline soils stabilised with Portland cement. (a) Close-up of specimen; (b, c) hydration products.

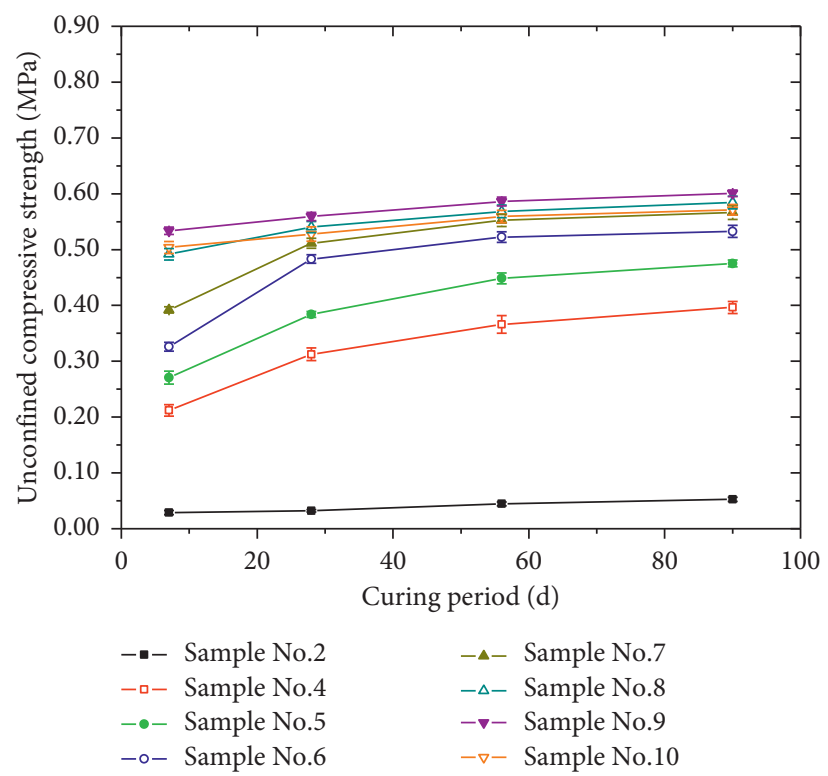

FIGURE 8: Influence of curing period on UCS of samples stabilised with $\mathrm{Ca}(\mathrm{OH})_{2}$ and GGBS.

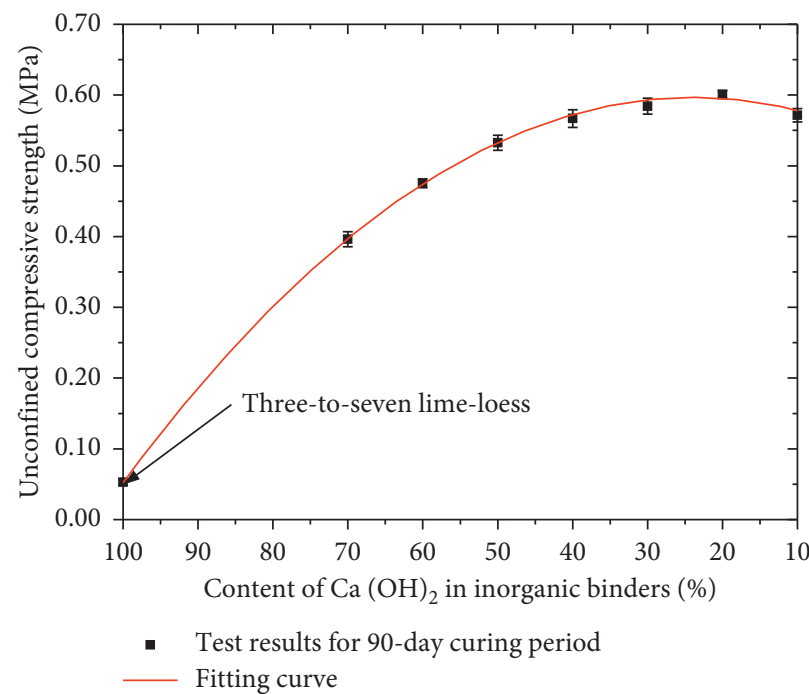

FIGURE 9: Influence of $\mathrm{Ca}(\mathrm{OH})_{2}$ content in inorganic binders on UCS of sample during $90 \mathrm{~d}$ curing period. 
Figures $10(\mathrm{a})-10$ (c) show the microstructure of saline soils stabilised with a mixture of $\mathrm{Ca}(\mathrm{OH})_{2}$ and GGBS. For the sample examined by scanning electron microscopy, the $\mathrm{Ca}(\mathrm{OH})_{2}$ content in inorganic binders is optimum (i.e., $20.0 \%$ ). As listed in Table 3, the contents of $\mathrm{CaO}$ and $\mathrm{SiO}_{2}$ in GGBS are high. The hydration reaction of the mixture of GGBS and $\mathrm{Ca}(\mathrm{OH})_{2}$ resulting in $\mathrm{C}_{5} \mathrm{~S}_{3} \mathrm{~A}$ can be expressed as follows [27]:

$$
\mathrm{C}_{5} \mathrm{~S}_{3} \mathrm{~A}+\mathrm{Ca}(\mathrm{OH})_{2}+\mathrm{H}_{2} \mathrm{O} \longrightarrow \mathrm{C}_{4} \mathrm{AH}_{13}+3 \mathrm{C}-\mathrm{S}-\mathrm{H}
$$

In this reaction, two types of hydration products are generated. Figure 10(a) shows that the soil particles are enclosed by hydration products. Figures 10(b) and 10(c) show two main types of hydration products: one resembles a reticular gel, and the other is similar to a lamellar crystal.

\subsection{Saline Soils Stabilised with Mixtures of $\mathrm{NaOH}$ and GGBS.}

Figure 11 shows the variation in the UCS of saline soils stabilised with $\mathrm{NaOH}$ and GGBS during the curing period. For samples $11,12,13,14,15,16,17$, and 18 listed in Table 6 , the mass ratio of $\mathrm{NaOH}$ to GGBS also varies for inorganic binders; however, the mass of inorganic binders is kept constant.

For the aforementioned samples, the $\mathrm{NaOH}$ content in inorganic binders is gradually increased. As indicated by Figure 11, the UCS of saline soils stabilised with inorganic binders also increases with the curing period. Based on this figure, the influence of $\mathrm{NaOH}$ content in inorganic binders on the UCS of samples during the $90 \mathrm{~d}$ curing period can be derived, as shown in Figure 12.

During the $90 \mathrm{~d}$ curing period, when the $\mathrm{NaOH}$ content in inorganic binders as an alkaline activator for GGBS does not exceed $1.04 \%$, the UCS of the sample does not improve, as indicated in Figure 12. When the $\mathrm{NaOH}$ content is further increased, the sample strength increases until it reaches the maximum (0.019 $\mathrm{MPa})$. However, upon reaching the maximum strength, further increasing the $\mathrm{NaOH}$ content does not improve the sample strength. When the $\mathrm{NaOH}$ content in inorganic binders is low, it cannot effectively stimulate GGBS. Similarly, when the $\mathrm{NaOH}$ content is excessively high, the redundant $\mathrm{NaOH}$ content does effectively stimulate the GGBS and impairs the sample strength.

Figures 13(a)-13(c) show the microstructure of saline soils stabilised with a mixture of $\mathrm{NaOH}$ and GGBS. For the sample examined by scanning electron microscopy, the $\mathrm{NaOH}$ content in inorganic binders is also the optimum content, that is, $3.64 \%$. The hydration reaction of the mixture of $\mathrm{NaOH}$ and GGBS can be expressed as follows [27]:

$$
\mathrm{C}_{5} \mathrm{~S}_{3} \mathrm{~A}+\mathrm{NaOH}+\mathrm{H}_{2} \mathrm{O} \longrightarrow \mathrm{C}_{4} \mathrm{AH}_{13}+\mathrm{C}-\mathrm{S}-\mathrm{H}+\mathrm{C}_{2} \mathrm{ASH}_{8}
$$

Equation (5) shows that three types of hydration products are generated. However, two types of hydration products are mainly generated in this test. As shown in Figures 13(b) and 13(c), one resembles a reticular gel, and the other is similar to a lamellar crystal. Furthermore, as indicated in Figure 13(a), numerous particles of saline soils are gathered together by the hydration products, significantly improving the sample strength.

3.4. Saline Soils Stabilised with Mixtures of $\mathrm{Na}_{2} \mathrm{CO}_{3}$ and GGBS. Figure 14 shows the variation in the UCS of saline soils stabilised with $\mathrm{Na}_{2} \mathrm{CO}_{3}$ and GGBS during the curing period. For samples 19, 20, 21, 22, and 23 listed in Table 6, the mass ratio of $\mathrm{Na}_{2} \mathrm{CO}_{3}$ to GGBS is varied; however, the mass of inorganic binders is kept constant.

For the aforementioned samples, the $\mathrm{Na}_{2} \mathrm{CO}_{3}$ content in inorganic binders is gradually increased. As indicated in Figure 14, the UCS of saline soils stabilised with inorganic binders also increases with the curing period. Based on this figure, the influence of $\mathrm{Na}_{2} \mathrm{CO}_{3}$ content in inorganic binders on the UCS of samples during the $90 \mathrm{~d}$ curing period can be derived, as shown in Figure 15.

With increasing $\mathrm{Na}_{2} \mathrm{CO}_{3}$ content in inorganic binders, the sample strength also increases until it reaches the maximum $(0.026 \mathrm{MPa})$, as indicated in Figure 15. However, further increasing the $\mathrm{Na}_{2} \mathrm{CO}_{3}$ content does not improve the sample strength; that is, the redundant $\mathrm{Na}_{2} \mathrm{CO}_{3}$ content cannot effectively stimulate GGBS. In addition, we also find that the maximum UCS shown in Figure 15 slightly improves compared with that of remoulded saline soil samples during the $90 \mathrm{~d}$ curing period. This indicates that $\mathrm{Na}_{2} \mathrm{CO}_{3}$ is not a suitable alkaline activator for GGBS in these tests.

Figures 16(a) and 16(b) show the microstructure of saline soils stabilised with a mixture of $\mathrm{Na}_{2} \mathrm{CO}_{3}$ and GGBS. For the sample shown in Figures 16(b) and 16(C), the $\mathrm{Na}_{2} \mathrm{CO}_{3}$ content in inorganic binders is $15.2 \%$, which is the optimum value. This indicates that the sample's UCS can reach the maximum. The hydration reaction for the mixture of $\mathrm{Na}_{2} \mathrm{CO}_{3}$ and GGBS can be expressed as follows [27].

$$
\mathrm{C}_{5} \mathrm{~S}_{3} \mathrm{~A}+\mathrm{Na}_{2} \mathrm{CO}_{3}+\mathrm{H}_{2} \mathrm{O} \longrightarrow \mathrm{C}_{4} \mathrm{AH}_{13}+\mathrm{C}_{2} \mathrm{ASH}_{8}
$$

Equation (6) indicates that two types of hydration products are generated. However, in this test, one hydration product is mainly observed. As shown in Figure 16(b), this product resembles a lamellar crystal. Furthermore, as displayed in Figure 16(a), numerous saline soil particles are piled up, and hydration products fill the spaces in between particles. This indicates that these saline soil particles are loose.

3.5. Saline Soils Stabilised with Mixtures of $\mathrm{Na}_{2} \mathrm{SO}_{4}$ and GGBS. Figure 17 shows the variation in the UCS of saline soils stabilised with $\mathrm{Na}_{2} \mathrm{SO}_{4}$ and GGBS during the curing period. For samples 24, 25, 26, 27, 28, 29, and 30 listed in Table 6, the mass ratio of $\mathrm{Na}_{2} \mathrm{CO}_{3}$ to GGBS is also varied.

For the same samples above, the $\mathrm{Na}_{2} \mathrm{SO}_{4}$ content in inorganic binders is gradually increased. The UCS of saline soils stabilised with inorganic binders increases with the curing period, as indicated in Figure 17. Based on this figure, the influence of $\mathrm{Na}_{2} \mathrm{SO}_{4}$ content in inorganic binders on the UCS of samples during the $90 \mathrm{~d}$ curing period can be derived, as shown in Figure 18. 


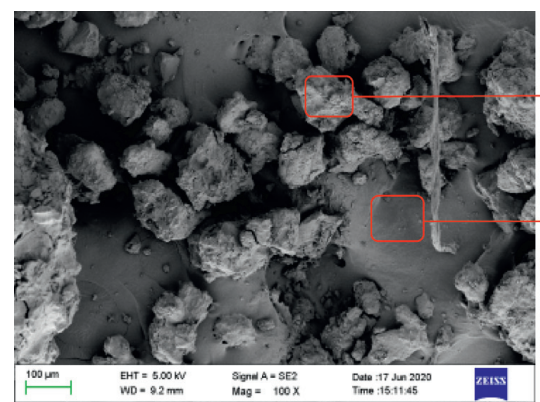

(a)

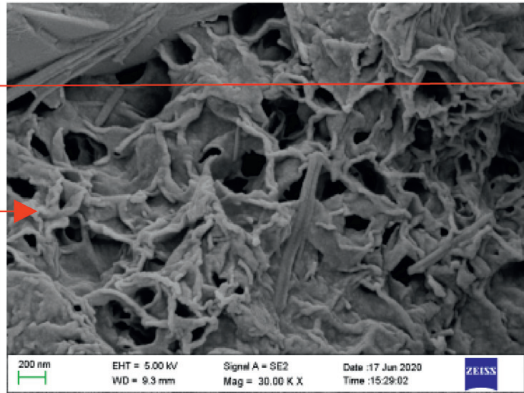

(b)

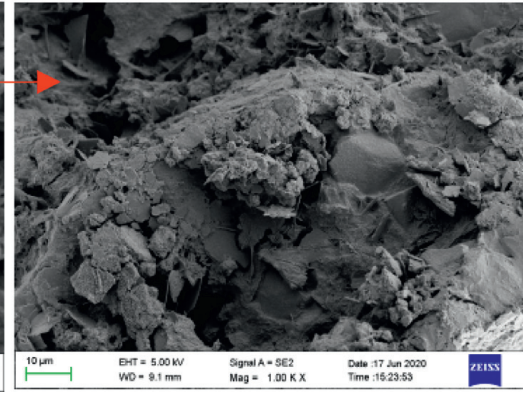

(c)

FIGURE 10: Microstructure of saline soils stabilised with $\mathrm{Ca}(\mathrm{OH})_{2}$ and GGBS. (a) Close-up of specimen; (b, c) hydration products.

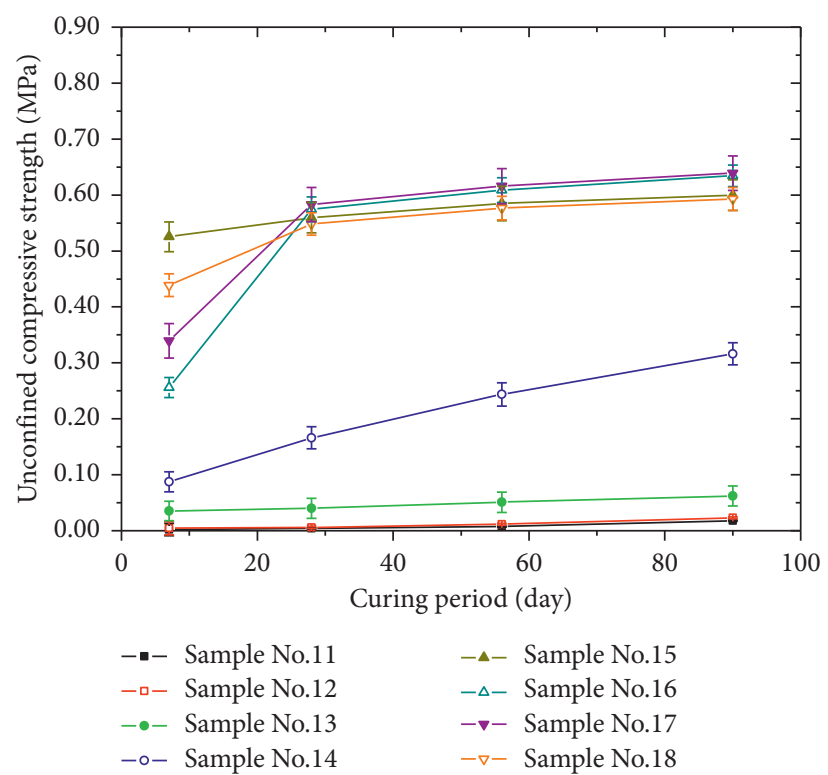

FIGURE 11: Influence of curing period on UCS of samples stabilised with $\mathrm{NaOH}$ and GGBS.

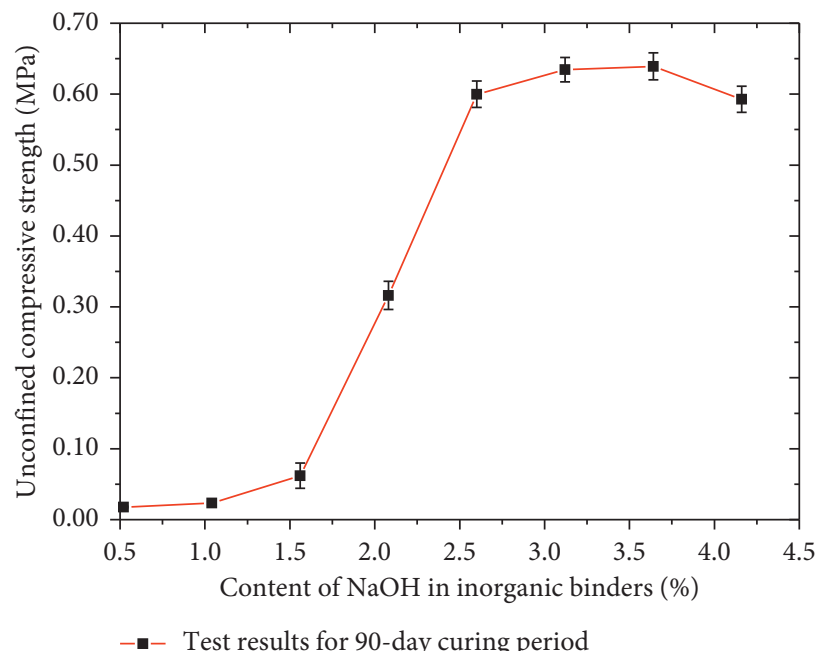

Figure 12: Influence of $\mathrm{NaOH}$ content in inorganic binders on UCS of sample during $90 \mathrm{~d}$ curing period. 


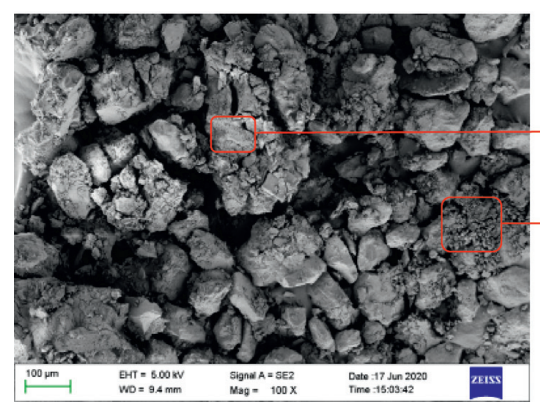

(a)

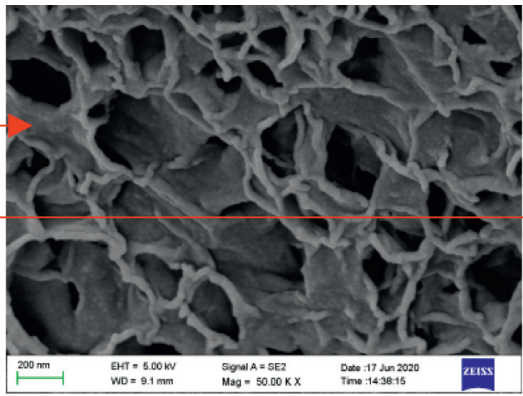

(b)

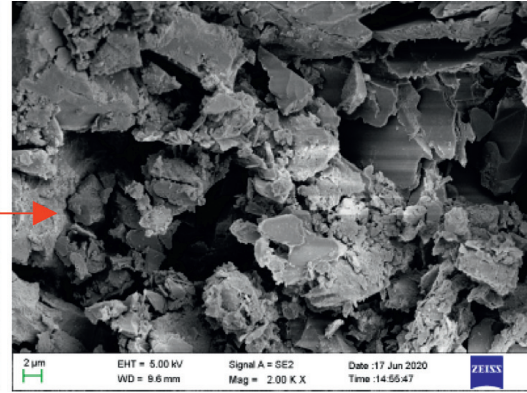

(c)

FIGURE 13: Microstructure of saline soils stabilised with NaOH and GGBS. (a) Close-up of specimen; (b) and (c) hydration products.

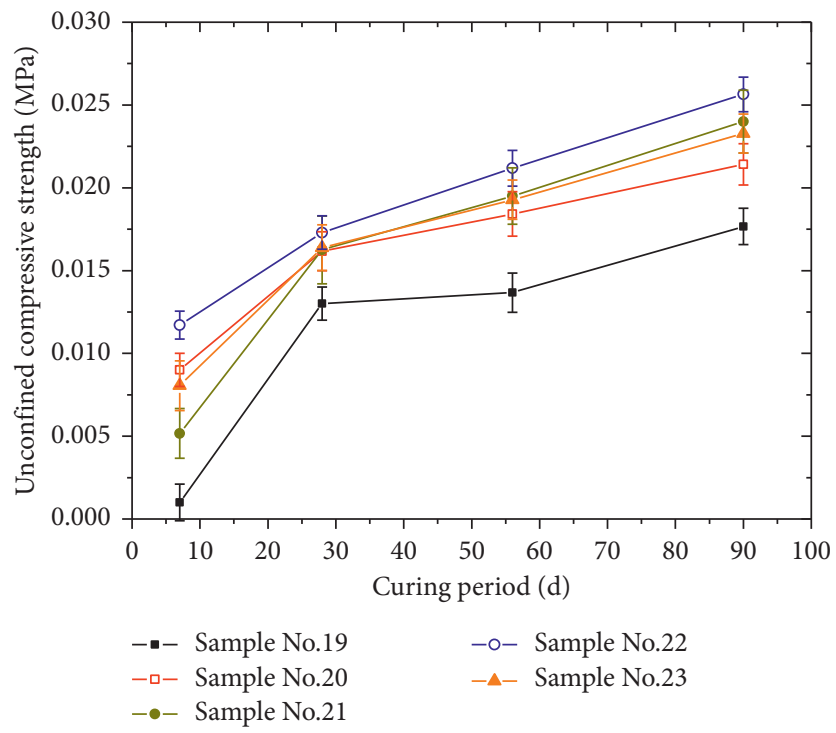

FIGURE 14: Influence of curing period on UCS of samples stabilised with $\mathrm{Na}_{2} \mathrm{CO}_{3}$ and GGBS.

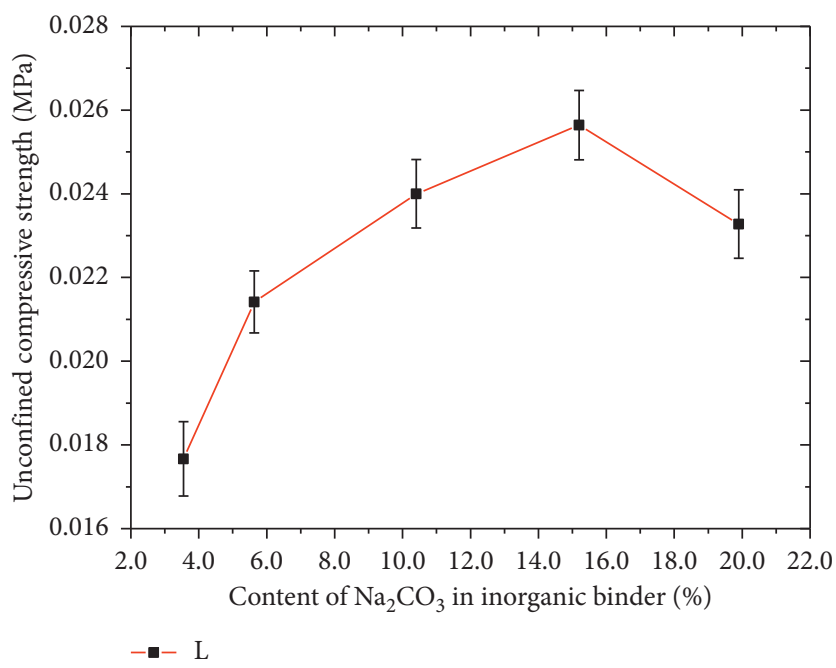

FIGURE 15: Influence of $\mathrm{Na}_{2} \mathrm{CO}_{3}$ content in inorganic binders on UCS of sample during the $90 \mathrm{~d}$ curing period. 


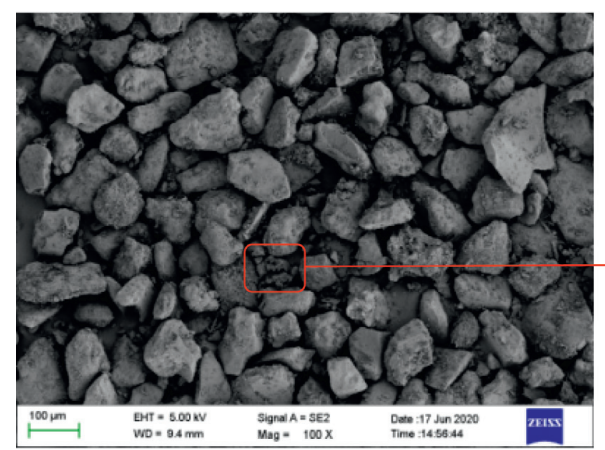

(a)

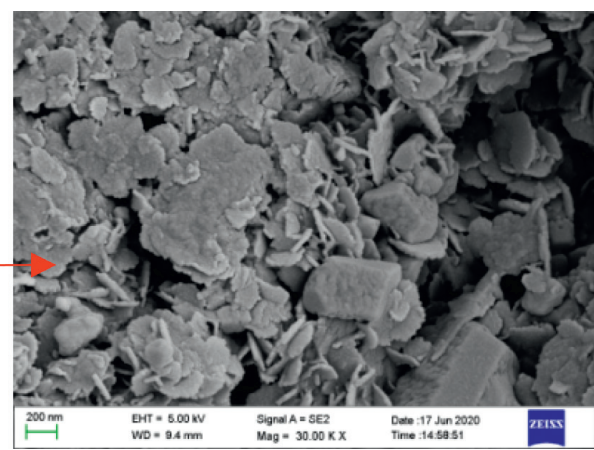

(b)

FIgURE 16: Microstructure of saline soils stabilised with $\mathrm{Na}_{2} \mathrm{CO}_{3}$ and GGBS. (a) Close-up of specimen; (b) hydration product.

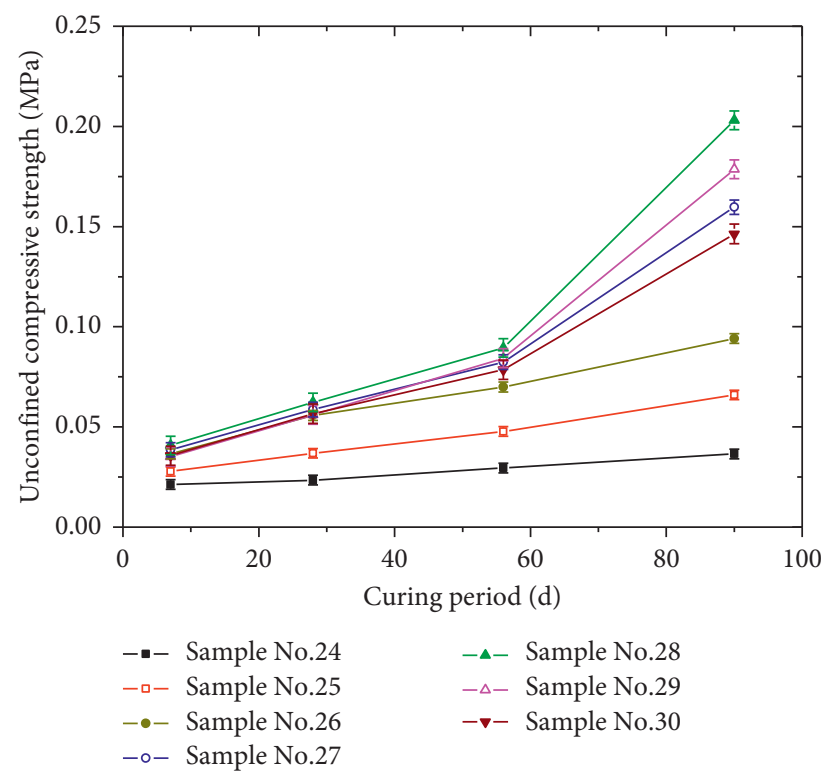

FIGURE 17: Influence of curing period on UCS of samples stabilised with $\mathrm{Na}_{2} \mathrm{SO}_{4}$ and GGBS.

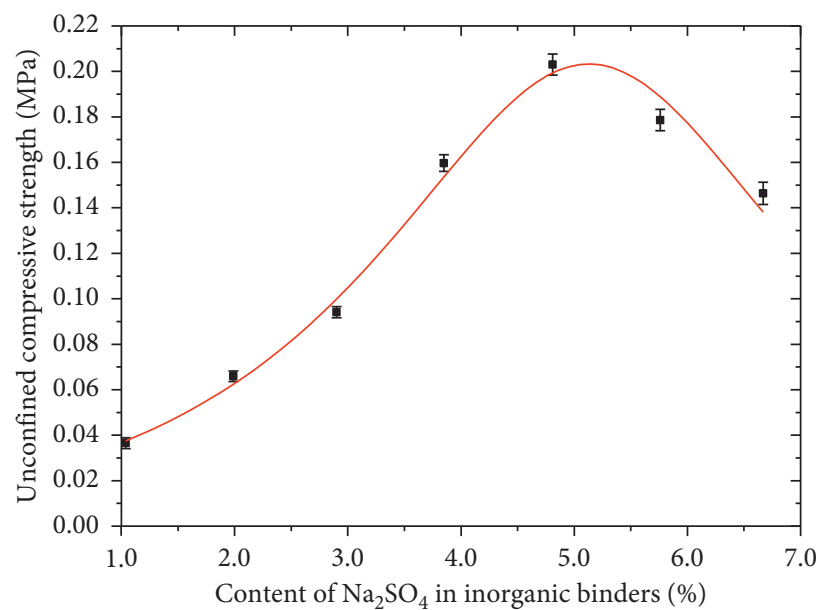

- Test results for 90-day curing period

- Fitting curve

FIGURE 18: Influence of $\mathrm{Na}_{2} \mathrm{SO}_{4}$ content in inorganic binders on UCS of sample at the $90 \mathrm{~d}$ curing period. 


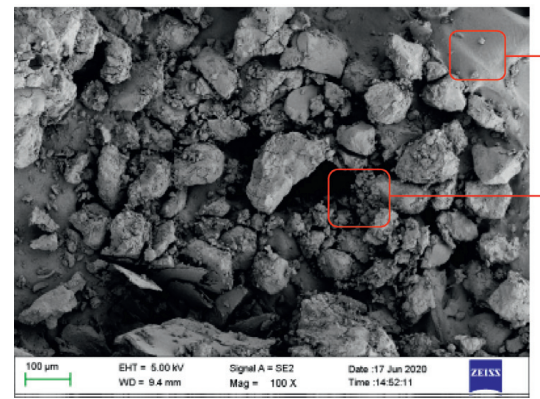

(a)

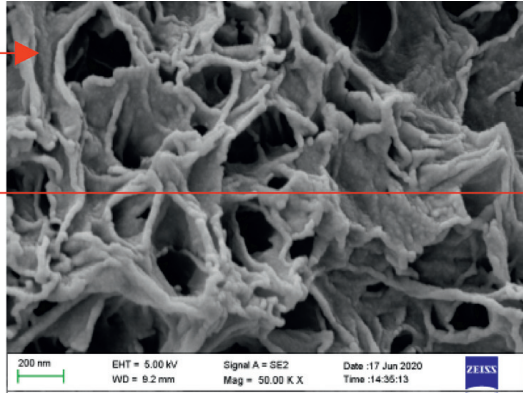

(b)

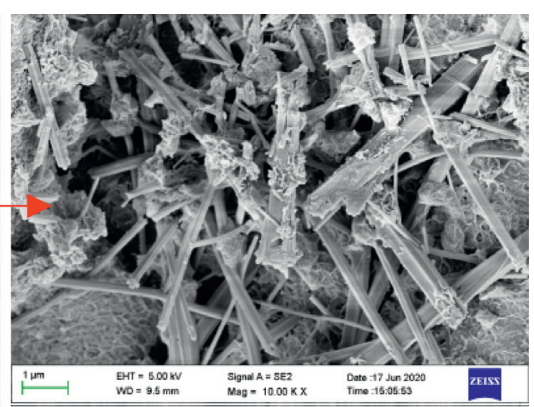

(c)

FIGURE 19: Microstructure of saline soils stabilised with $\mathrm{Na}_{2} \mathrm{SO}_{4}$ and GGBS. (a) Close-up of specimen; (b) hydration products.

With increasing $\mathrm{Na}_{2} \mathrm{SO}_{4}$ content in inorganic binders, the sample strength also increases until it reaches the maximum $(0.203 \mathrm{MPa})$, as shown in Figure 18. However, further increasing the $\mathrm{Na}_{2} \mathrm{SO}_{4}$ content in inorganic binders does not improve the sample strength. To the contrary, the redundant $\mathrm{Na}_{2} \mathrm{SO}_{4}$ content reduces the sample's UCS. Based on the test results during the $90 \mathrm{~d}$ curing period, the fitting curve for the relationship between the UCS and $\mathrm{Na}_{2} \mathrm{SO}_{4}$ content can be expressed as follows:

$$
P_{u}=\frac{2.04+4.12 T}{1-3.38 T+3.57 T^{2}},
$$

where $P_{u}$ represents the UCS $(\mathrm{MPa})$ and $T$ represents the $\mathrm{Na}_{2} \mathrm{SO}_{4}$ content in inorganic binders (\%). Moreover, in equation (7), parameter $T$ is in the range $1.0 \%-6.7 \%$.

Figures 19(a)-19(c) show the microstructure of saline soils stabilised with a mixture of $\mathrm{Na}_{2} \mathrm{SO}_{4}$ and GGBS. For the sample examined by scanning electron microscopy, the $\mathrm{Na}_{2} \mathrm{SO}_{4}$ content in inorganic binders is $4.81 \%$, which is the optimum content. The hydration reaction for the mixture of $\mathrm{Na}_{2} \mathrm{SO}_{4}$ and GGBS can be expressed as follows [27]:

$$
\mathrm{C}_{5} \mathrm{~S}_{3} \mathrm{~A}+\mathrm{Na}_{2} \mathrm{SO}_{4}+\mathrm{H}_{2} \mathrm{O} \longrightarrow \mathrm{C}-\mathrm{S}-\mathrm{H}+\mathrm{C}_{3} \mathrm{~A} \cdot 3 \mathrm{CaSO}_{4} \cdot 32 \mathrm{H}_{2} \mathrm{O}
$$

Equation (8) indicates that two types of hydration products are generated. Figure 19(a) shows that some saline soil particles are bonded together by the hydration products, and some particles are piled up. In this test, two types of hydration products are mainly generated. As shown in Figures 19(b) and 19(c), one resembles a reticular gel, and the other is similar to an acicular crystal.

\section{Conclusions}

A series of unconfined compressive tests were implemented to investigate the stabilisation effect of alkali-activated GGBS on saline soils. In addition, scanning electron microscopy was performed to determine the morphology of hydration products of alkali-activated GGBS. The following conclusions are drawn:

(1) The mixture of $\mathrm{Ca}(\mathrm{OH})_{2}$ and GGBS can stabilise saline soils, indicating that $\mathrm{Ca}(\mathrm{OH})_{2}$ can effectively stimulate GGBS. In this test, the optimum content of $\mathrm{Ca}(\mathrm{OH})_{2}$ in inorganic binders was $20.0 \%$.
(2) When the mixture of $\mathrm{NaOH}$ and GGBS is used to stabilise saline soils, the optimum content of $\mathrm{NaOH}$ in inorganic binders is $3.64 \%$, which is considerably less than the optimum content of $\mathrm{Ca}(\mathrm{OH})_{2}$ in inorganic binders.

(3) The maximal UCS of saline soils stabilised with $\mathrm{Na}_{2} \mathrm{SO}_{4}, \mathrm{Na}_{2} \mathrm{CO}_{3}$, and GGBS during the $90 \mathrm{~d}$ curing period was considerably less than that of saline soils stabilised with $\mathrm{NaOH}$ or $\mathrm{Ca}(\mathrm{OH})_{2}$ and GGBS during the same curing period. The mixture of $\mathrm{Na}_{2} \mathrm{CO}_{3}$ and GGBS cannot significantly improve the UCS of saline soil compared with that of remoulded saline soil. Moreover, $\mathrm{Na}_{2} \mathrm{CO}_{3}$ is not a suitable alkaline activator for GGBS.

(4) The morphology of the hydration products of samples varies because of the different alkaline activators involved in the hydration reaction with GGBS.

\section{Data Availability}

All the data used to support the findings of this study are included in this article.

\section{Conflicts of Interest}

The authors declare that there are no conflicts of interest regarding the publication of this paper.

\section{Acknowledgments}

The authors are grateful for the input received from industry professionals who participated in this research. This work was financially supported by the National Natural Science Foundation of China (Grant no. 51908430) and the Science and Technology Project of High-Tech Zone in Weifang (Grant no. 2019KJHM09).

\section{References}

[1] Y. C. Liu, H. Li, and Y. F. Xu, "Research on engineering properties of saline-alkaline soils in littoral area," Subgrade Engineering, vol. 3, pp. 57-60, 2007. 
[2] M. Jafari, A. Tavili, F. Panahi, E. Zandi Esfahan, and M. Ghorbani, "Amendment of saline and alkaline soils," Environmental Science and Engineering, vol. 4, pp. 167-174, 2018.

[3] M. Abdullah, N. Al-Ansari, N. Adamo et al., "Soil salinity of mesopotamia and the main drains," Journal of Earth Sciences and Geotechnical Engineering, vol. 10, no. 4, pp. 221-230, 2020.

[4] Y. Wang, S. Dou, L. Wang et al., "Salinity variability of soda meadow alkaline soil in different depths of subsurface pipe," Polish Journal of Environmental Studies, vol. 27, no. 6, pp. 2801-2809, 2018.

[5] T. Masumitsu, S. Tatsuaki, W. Mikio, I. Tomoharu, and M. Kazuaki, "Development of cement material using inorganic additives," Journal of Nuclear Fuel Cycle and Environment, vol. 3, no. 2, pp. 35-43, 1997.

[6] J. W. Akitt, "Some observations on the greenhouse effect at the Earth's surface," Spectrochimica Acta Part A: Molecular and Biomolecular Spectroscopy, vol. 188, pp. 127-134, 2018.

[7] O. Altun, "Energy and cement quality optimization of a cement grinding circuit," Advanced Powder Technology, vol. 29, no. 7, pp. 1713-1723, 2018.

[8] S. Jegandan, M. Liska, A. A.-M. Osman, and A. Al-Tabbaa, "Sustainable binders for soil stabilisation," Proceedings of the Institution of Civil Engineers - Ground Improvement, vol. 163, no. 1, pp. 53-61, 2010.

[9] A. Kavak, G. Bilgen, and O. F. Capar, "Using ground granulated blast furnace slag with seawater as soil additives in lime-clay stabilization," Journal of ASTM International, vol. 8, no. 7, Article ID 103648, 2011.

[10] Y. D. Laxmikant, "Stabilization of soft soil with granulated blast furnace slag and fly ash," International Journal of Renewable Energy Technology, vol. 2, no. 2, pp. 115-119, 2013.

[11] A. M. Rashad, "A brief on high-volume Class F fly ash as cement replacement - a guide for Civil Engineer," International Journal of Sustainable Built Environment, vol. 4, no. 2, pp. 278-306, 2015.

[12] A. M. Rashad, "An overview on rheology, mechanical properties and durability of high-volume slag used as a cement replacement in paste, mortar and concrete," Construction and Building Materials, vol. 187, pp. 89-117, 2018.

[13] Y. Yi, M. Liska, F. Jin, and A. Al-Tabbaa, "Mechanism of reactive magnesia - ground granulated blastfurnace slag (GGBS) soil stabilization," Canadian Geotechnical Journal, vol. 53, no. 5, pp. 773-782, 2016.

[14] A. Thomas, R. K. Tripathi, and L. K. Yadu, "A laboratory investigation of soil stabilization using enzyme and alkaliactivated ground granulated blast-furnace slag," Arabian Journal for Science and Engineering, vol. 43, no. 10, pp. 5193-5202, 2018.

[15] J. Payá, J. Monzó, J. Roselló, M. V. Borrachero, A. Font, and L. Soriano, "Sustainable soil-compacted blocks containing blast furnace slag (BFS) activated with olive stone biomass ash (OBA)," Sustainability, vol. 12, no. 23, p. 9824, 2020.

[16] Y. L. Yi, C. Li, C. Sun et al., "Test on alkali-activated ground granulated blast furnace slag for lianyungang soft soil stabilization," Chinese Journal of Rock Mechanics and Engineering, vol. 32, no. 9, pp. 1820-1826, 2013.

[17] GB50007-2011, Code for Design of Building foundation, Ministry of Housing and Urban Rural Development of the People's Republic of China, China Architecture \& Building Press, Beijing, China, 2018.

[18] GB50021-2009, Code for Investigation of Geotechnical Engineering, Ministry Of Housing and Urban Rural Development of the People's Republic of China and General Administration Of
Quality Supervision, Inspection And Quarantine Of the People's Republic of China, China Architecture \& Building Press, Beijing, China, 2018.

[19] GB/T 50942-2014, Technical Code for Building in saline Soil Regions, Ministry Of Housing and Urban Rural Development of the People's Republic of China and General Administration Of Quality Supervision, Inspection And Quarantine Of the People's Republic of China, China Planning Press, Beijing, China, 2018.

[20] JTG E51-2009, Test Method of Materials Stabilized with Inorganic Binders for Highway Engineering, Research Institute of Highway Ministry of Transport, China Communications Press, Beijing, China, 2009.

[21] JTG/T 233-2011, Specification for Mix Proportion Design of Cement Soil, Ministry Of Housing and Urban Rural Development of the People's Republic of China, China Architecture $\&$ Building Press, Beijing, China, 2011.

[22] C. J. Shi, P. V. Krivenko, and D. Roy, Alkali-activated Cements and Concretes, Taylor \& Francis, New York, 2006.

[23] H. Z. Mi, J. M. Huang, and Y. N. Hu, "Experiment on constitutive relation and strength properties of three-to-seven lime-loess," Journal of Architecture and Civil Engineering, vol. 31, no. 2, pp. 112-118, 2014.

[24] Z. Wang, H. W. Zheng, J. S. Qian et al., "A study on comparison of sulfate activating fly ash," Fly Ash Comprehensive, vol. 3, pp. 15-18, 1999.

[25] Gb/T. 50123-2019, Standard for Soil Test Method, Ministry Of Housing and Urban Rural Development of the People's Republic of China and General Administration Of Quality Supervision, Inspection And Quarantine Of the People's Republic of China, China Planning Press, Beijing, China, 2019.

[26] R. James, A. H. M. Kamruzzaman, A. Haque, and A. Wilkinson, "Behaviour of lime-slag-treated clay," Proceedings of the Institution of Civil Engineers - Ground Improvement, vol. 161, no. 4, pp. 207-216, 2008.

[27] I. A. Voinovitch and R. Dron, "Action of different activators on the hydration of slag," Silicates Industriels, vol. 41, no. 9, pp. 209-212, 1976. 